\title{
研究報文
}

\section{東日本大震災による津波被災紙中に 存在する糸状菌の同定}

\section{Identification of Filamentous Fungi in Paper Damaged by Tsunami of the Great East Japan Earthquake}

\author{
東京大学大学院 ${ }^{* 1}$ 農学生命科学研究科 \\ 東嶋健太 ${ }^{* 2}$, 和田朋子, 五十嵐圭日子, \\ 江前敏晴, 鮫島正浩, 磯貝 明

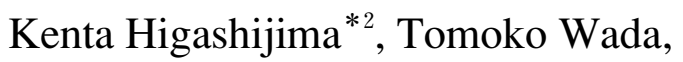 \\ Kiyohiko Igarashi, Toshiharu Enomae, \\ Masahiro Samejima and Akira Isogai \\ Graduate School of Agricultural and Life Sciences, The University of Tokyo*1
}

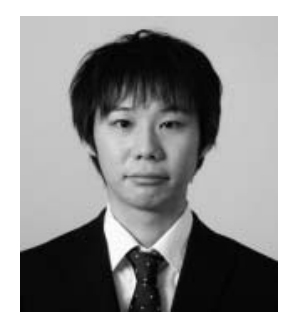

東嶋健太

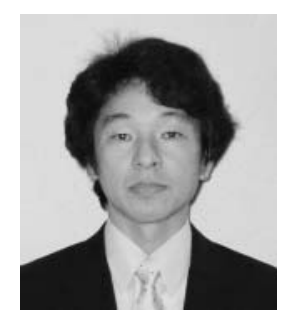

江前敏晴

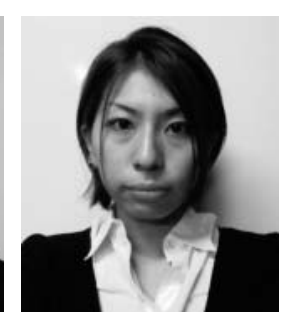

和田朋子

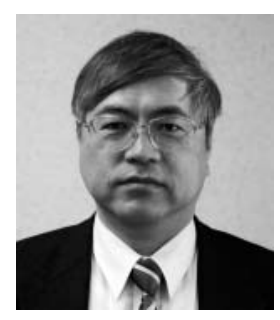

鮫島正浩

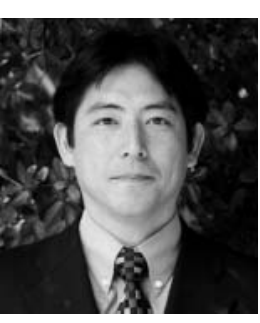

五十嵐圭日子

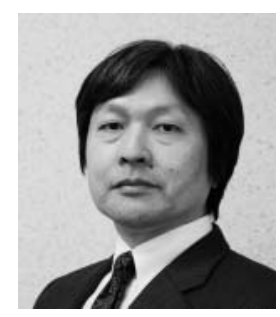

磯貝 明

\begin{abstract}
We are developing a new easy-to-use method for rescuing flood-damaged paper by using salt water.

In this study, filamentous fungi in paper damaged by tsunami of the Great East Japan Earthquake were identified by the method which can detect sensitively filamentous fungi in a small sample and the results were discussed for practical use of the salt water method. No filamentous fungi were detected in tsunami-damaged paper without mud sampled in paper products storage in the Ishinomaki mill of Nippon Paper Industries Co., Ltd., but Penicillium fungi were mainly detected in paper undamaged by tsunami sampled in the same place. This suggests that the effect of salt water on the inhibition of fungal growth for osmotic pressure would appear after paper was wetted by tsunami until it dried.

On the other hand, various filamentous fungi were detected in tsunami-damaged paper with mud sampled in the same place. Tsunami-damaged paper with mud was likely to bring about fungal growth at high relative humidity, probably because numerous bacteria and fungi live in mud that is very rich in nutrition. This result shows mud on flood-damaged paper must be washed away with salt water or fresh water to remove fungi and nutrition. Alternaria fungi were mainly detected in paper damaged by tsunami and left for about 3 months outside the Hachinohe mill of Mitsubishi Paper Mills Limited. The salt amount in tsunami-damaged paper left out-
\end{abstract}

\footnotetext{
${ }^{* 1}$ T113-8657 東京都文京区弥生 1-1-1/1-1-1 Yayoi, Bunkyo-ku, Tokyo 113-8657, Japan

${ }^{* 2} \mathrm{E}-$ mail : kenta-higashijima@ojipaper.co.jp
} 
side was considered to decrease because the salt was removed by rain and dew condensation. So, the effect of salt water on preventing fungal growth was lost and fungi such as Alternaria fungi grew on tsunami-damaged paper left outside. This result shows that the decrease in the salt concentration must be avoided during the emergency conservation of flood-damaged paper with salt water.

Keywords : filamentous fungi identification, mold, salt water method, seawater, tsunami-damaged paper 分類： $\mathrm{Y}_{0}$ その他, $\mathrm{Y}_{7}$ 生物学・バイオテクノロジー

\section{1. 緒言}

2011 年 3 月 11 日に発生した東日本大震災による津波で, 大量の紙媒体文書類が津波被災した。集中豪雨による洪水 や地震による津波によって水害被災した紙文書類や紙文化 財の緊急の課題はカビの繁殖を抑えることである。カビは 適度な水分があれば，紙の成分（セルロース，デンプン， 合成高分子）を栄養分として繁殖する他, 空気中に飛散し ている塵や埃なども栄養分としながら紙を足場としてだけ 利用することもある。行政文書や図書類などの紙文書類の 場合, カビが繁殖することにより, 記載文字の判読ができ なくなる可能性や, 不衛生で異臭を伴うため保管の意欲が 失せて乾燥後も捨てざるを得なくなる可能性がある。紙文 化財の場合は, カビの菌糸や代謝物に由来する着色によっ て美術的価值が著しく損なわれる上, 長期的な保管中に紙 の物理的化学的劣化が進行することが予想される。

現在では，水害被災した紙文化財は真空凍結乾燥法によ って対処することが望ましいとされている。しかし，真空 凍結乾燥法は電源, 大きな冷凍装置, 乾燥工程に移るまで の長期にわたる冷凍保管, および高価な乾燥装置が必要と なるため, 被桨地や発展途上国では現実的な方法とは言い 難い。またエタノールを紙に噴霧することでカビの繁殖を 抑える方法が文化財修復家の間で一般的な対処法として用 いられている。しかし，エタノール噴霧によりバクテリア は死滅するが, カビや酵母は死滅しない。2004 年に国宝 高松塚古墳壁画にカビが大量発生し, 西壁「白虎」の著し い劣化が報道され関心を集めたが，この事件をきっかけに エタノール噴霧はカビの繁殖抑制に実質的な効果がなく, カビを完全に殺菌するためには数十分間高濃度のアルコー ルに浸漬する必要があることや, 低濃度のアルコールでは 微生物の栄養源（炭素源）として利用される可能性がある ことが認知されるようになった ${ }^{1-4)}$ 。またエタノールは毒性 と引火性があるため, 大量の水害被災紙を救済するために 長期間の作業が予想される場合には取り扱いに十分な注意 が必要とされる。

そこで著者らは水害被災した紙文書類や紙文化財をすぐ に完全に乾燥できない場合において, 紙を塩水に浸漬する という簡便な処置でカビの繁殖を防ぐ緊急保存法の確立を 目指している。これまでの研究から, 海水塩や塩化ナトリ ウムで調製した濃度 $3.5 \%$ 以上の塩水に紙を浸漬すること で，塩水の浸透圧の効果によりカビの繁殖をほとんど抑え られることが明らかとなった ${ }^{5-7)}$ 。また, 塩水に浸漬した紙 を取り出し, 水で洗浄する脱塩処理または吸水紙で拭き取 る脱塩処理により, 紙に残存する塩を効果的に除去できる
ことが明らかとなった ${ }^{8)}$ 。この塩水による緊急保存法のア イデアは，2004年にインドネシアのアチェ地区の大津波 で水没した 16 トンの土地台帳が需れたまま熱帯で 2 ケ月 以上放置されたにもかかわらず，カビがほとんど繁殖しな かったという報告 ${ }^{9}$ から得た。高濃度塩の作用によるカビ の抑制であると推定し，これを技術に進展させることを立 案した。

本研究では, まず東日本大震災で市街地を襲った津波の 塩濃度を推定するために, 被災地周辺の海水の塩濃度測定 を行った。次に, カビの繁殖の確認は目視だけでは不完全 と考え, 和田らが開発した非特異的 DNA 増幅法を利用し て極微量の糸状菌を同定できる手法 ${ }^{10,11}$ を用いて，東日本 大震災による津波被災紙中の糸状菌の存在の確認および菌 種同定を行った。得られた結果から現在開発中の塩水保存 法の実用化に関する考察を行った。なお，糸状菌とは，紙 に繁殖する主要な菌として知られる子のう菌（カビ）と担 子菌（キノコ）の総称である。また，非特異的 DNA 増幅 法とは, Phi 29 DNA ポリメラーゼを用いてゲノム DNA に含まれる特定の塩基配列ではないすべての配列領域を増 幅する手法のことである。この手法は, 少量の試料中に存 在する極微量の糸状菌を検出および菌種同定できる手法で あり，前報ではわずか $1 \mathrm{mg}$ 程度の木粉からの菌種同定に 成功した ${ }^{10)}$ 。

\section{2. 実験}

\section{1 試料採取地周辺の海水の塩濃度測定}

2011 年 5 月 12 日に日本製紙石巻工場付近で採取した海 水と 2011 年 6 月 21 日に三菱製紙八戸工場付近で採取した 海水の塩濃度を屈折率計（MASTER-S/MillM，(株アタゴ) および自動温度補正付き電導度計（YK-31 SA, Lutron Electronic Enterprise Co., Ltd.) で測定した。それぞれの 海水の採取地点を Fig. 1 の地図上で×印で示す。日本製 紙石巻工場付近で海水を採取した地点は, 旧北上川河口か ら約 $1 \mathrm{~km}$ ，定川河口から約 $3 \mathrm{~km}$ 離れていた。三菱製紙 八戸工場付近で海水を採取した地点は，五戸川の河口と馬 淵川の河口からそれぞれ約 $3 \mathrm{~km}$, 奥入瀬川の河口から約 $5 \mathrm{~km}$ 離れていた。

\section{2 津波被災紙試料の採取}

2011 年 5 月 12 日に日本製紙石巻工場の倉庫内で塗工紙 (Coated paper) と上質紙（Fine paper）の 2 種類の紙試 料から，（a）津波に浸水した部分，（b）津波による浸水 を免れた部分，（c）津波に浸水して泥が付着している部分 をそれぞれ採取した。塗工紙と上質紙の成分等の詳細につ いては Table 1 に示す。採取地点を Fig. 1 の地図上で○印 


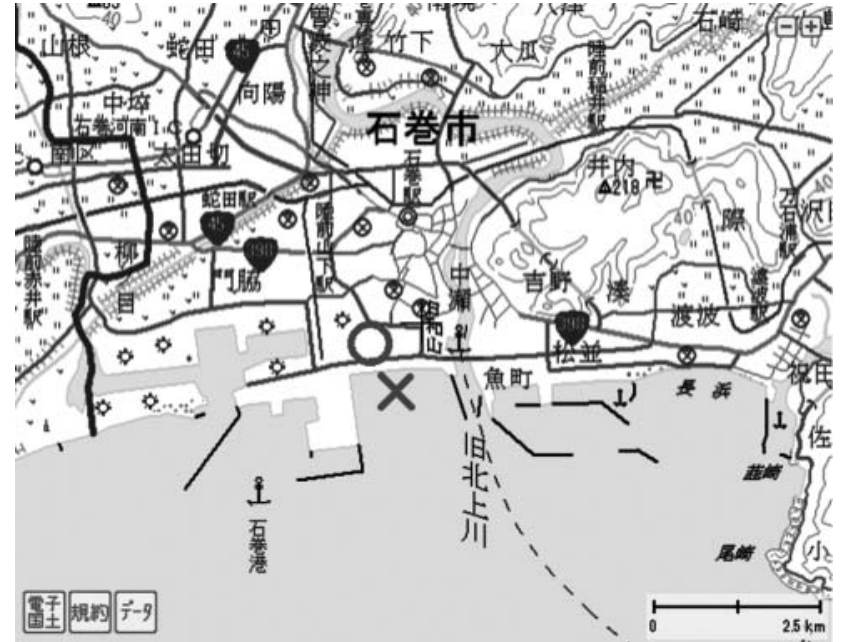

(a) Vicinity of Ishinomaki mill

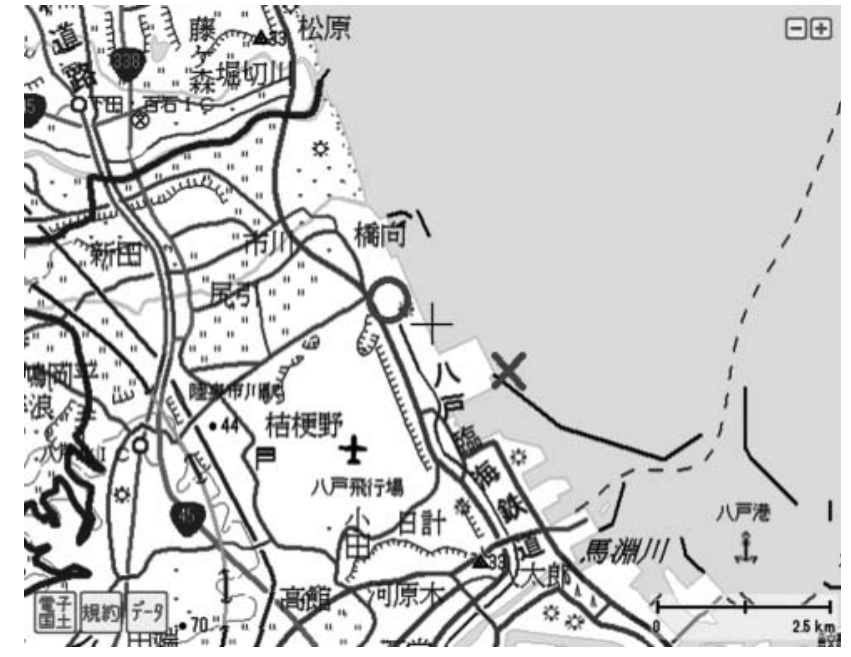

(b) Vicinity of Hachinohe mill

Fig. 1 Sampling spots of seawater and tsunami-damaged paper (maps provided from Digital Japan Web System ${ }^{\circledR}$ ). The cross mark indicates sampling spot of seawater. The red circle mark indicates sampling spot of tsunami-damaged paper.

Table 1 Details of coated paper and fine paper sampled in Ishinomaki mill

\begin{tabular}{|c|c|c|}
\hline Kind of paper & Coated paper & Fine paper \\
\hline Basis weight $\left(\mathrm{g} / \mathrm{m}^{2}\right)$ & 64.0 & 81.4 \\
\hline Fiber furnish & $\operatorname{BKP}(\operatorname{HBKP}($ main $)+\mathrm{SBKP}) \quad 85 \%+\mathrm{DIP} 15 \%$ & HBKP \\
\hline Pigment & GCC (main) + Kaolin clay & None \\
\hline Binder & Latex and oxidized starch & None \\
\hline Coat weight $\left(\mathrm{g} / \mathrm{m}^{2}\right)$ & $19 \sim 20$ (total of both sides) & 0 \\
\hline
\end{tabular}
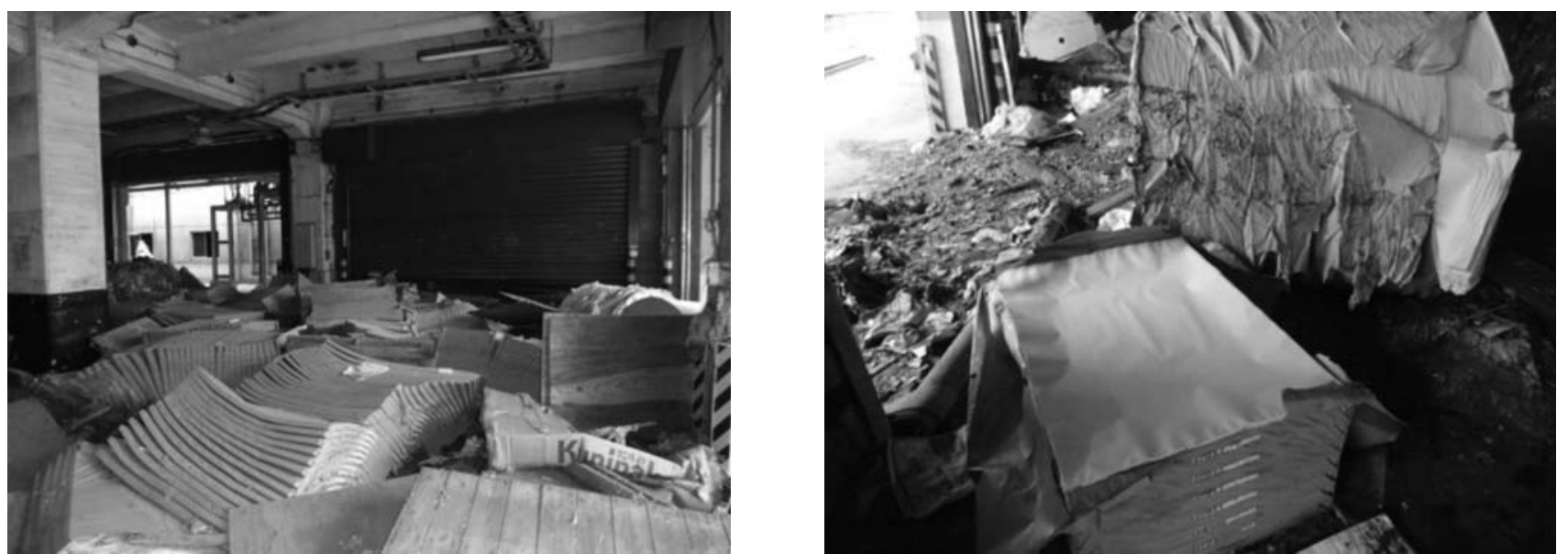

Photo. 1 Paper products storage where tsunami-damaged papers were sampled in Ishinomaki mill.

で示す。採取場所の写真をPhoto. 1 に示す。採取した紙 試料は屋内にあったので，海水や泥には触れていたが，そ の後の雨には当たっていない。

2011 年 6 月 21 日に三菱製紙八戸工場の敷地内で，津波 によって倉庫から外に流されて約 3 か月間屋外放置されて いた（d）非塗工紙（Uncoated paper）の紙試料を採取し た。この紙試料の成分等の詳細は非公表である。採取地点 を Fig. 1 の地図上で○印で示す。この試料は一部雨水に濡
れた形跡（Photo.2の下部）があり，その部分にカビの繁 殖が観察できた。

石巻工場で採取した計 6 種の紙試料と八戸工場で採取し た 1 種の紙試料を菌の同定試験のために $50 \mathrm{~mm} \times 50 \mathrm{~mm}$ の試験片に切り取って, 系状菌同定試験に供した。石巻工 場で採取した上質紙（c）と八戸工場で採取した非塗工紙 （d）は，明らかに複数種の菌が繁殖していたため，3つの 試験片から菌を同定したが，他の試料は 1 試験片ずつ菌同 


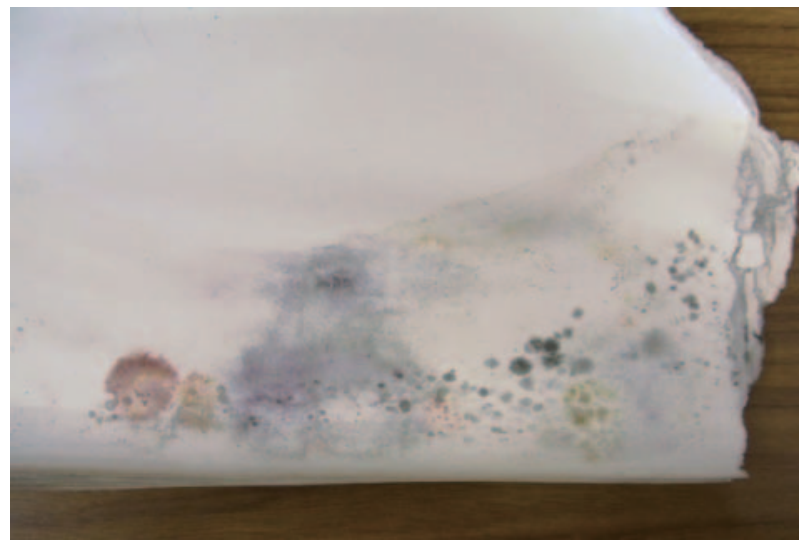

Photo.2 Tsunami-damaged Uncoated paper left outside Hachinohe mill for 3 months.

定を行った。菌同定を行った試験片の写真をPhoto. 3 に 示す。
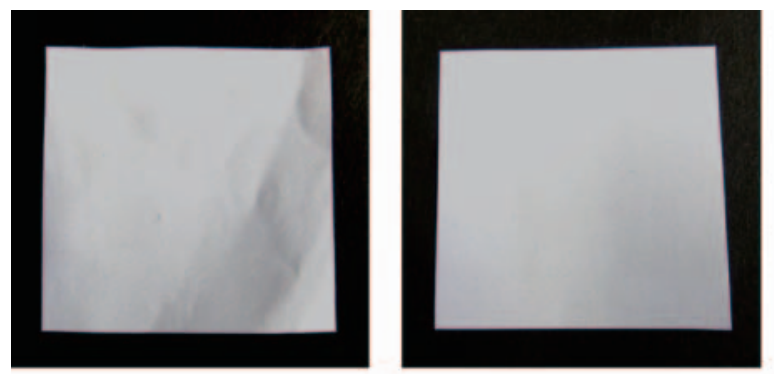

Coated paper (a)

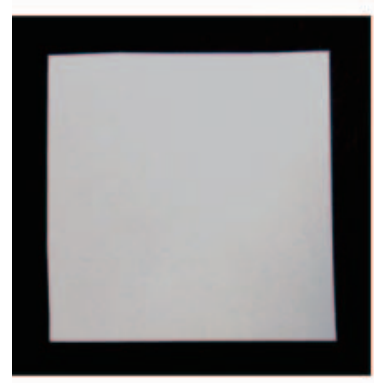

Fine paper (b)

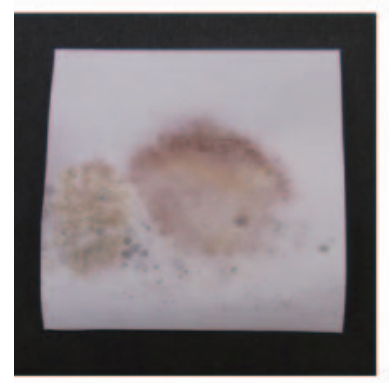

Uncoated paper (d) 1

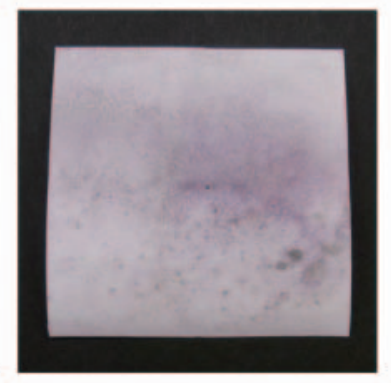

Uncoated paper (d)2

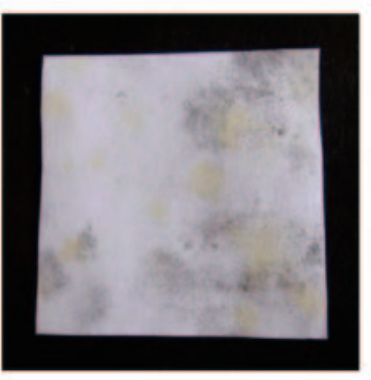

Fine paper (c) 1

\section{3 非特異的 DNA 増幅法を利用した担子菌類の同定}

和田らが開発した非特異的 DNA 増幅法を利用した同定 手法を用いて ${ }^{10)}$ ，2.1 で採取した津波被災紙試料中に存在 する糸状菌の同定を行った。実験スキームは Fig. 2 に示 す通りである。はじめに，各試験片をマルチビーズショッ カー (安井器械株) を用いて, 液体窒素下, $2,500 \mathrm{rpm}$ で 8 分間粉砕した。その後, DNeasy Plant Mini Kit（株キア ゲン）を用いて，説明書に従い粉砕後の試料からゲノム DNA を抽出した。その後各ゲノム DNA 抽出液を鋳型と して, Phi 29 DNA ポリメラーゼ (RepliPHI ${ }^{\mathrm{TM}}$, EPICENTRE）を用いて非特異的に，つまりゲノム DNA のすべて の塩基配列領域に，増幅反応を行った ${ }^{10)}$ 。非特異的増幅後 の反応液 $1 \mu \mathrm{L}$ を鋳型として，Fig. 2 に示した rDNAの ITS region (Internal Transcribed Spacer region : ITS 領 域）を系状菌に特異的なプライマー対を用いて，和田らの 報告 ${ }^{11}$ の通りに PCR (Polymerase Chain Reaction) 増幅 した。DNA の増幅が確認できた PCR 産物のみから DNA 断片をべクター（pCR ${ }^{\circledR} 4$ Blunt-TOPO vector，インビト

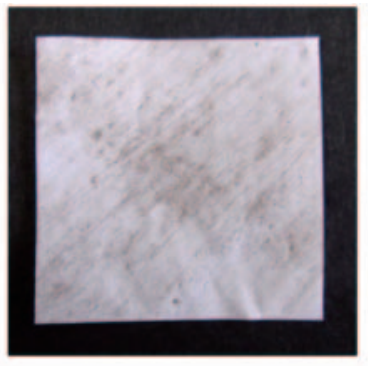

Coated paper (c)

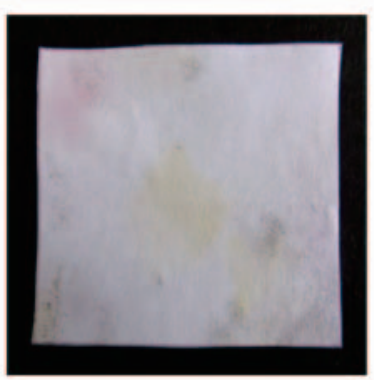

Fine paper (c)2

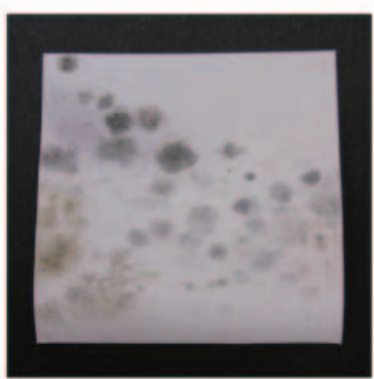

Uncoated paper (d) 3

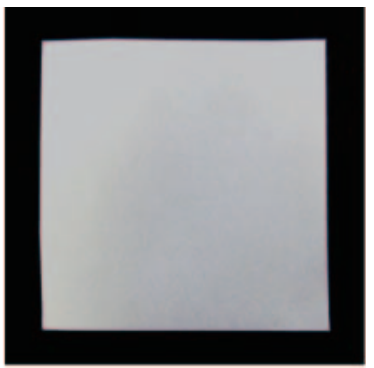

Fine paper (a)

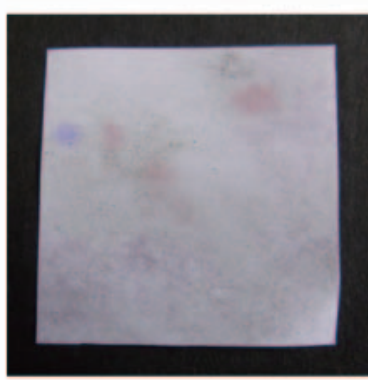

Fine paper (c)3

Photo. 3 Paper samples for identification of filamentous fungi. Coated paper and fine paper were sampled in paper products storage in Ishinomaki mill. Uncoated paper was sampled in outside of Hachinohe mill. (a) Paper damaged by tsunami without mud, (b) Paper undamaged by tsunami, and (c) Paper damaged by tsunami with mud. (d) Paper damaged by tsunami and left outside for 3 months. 

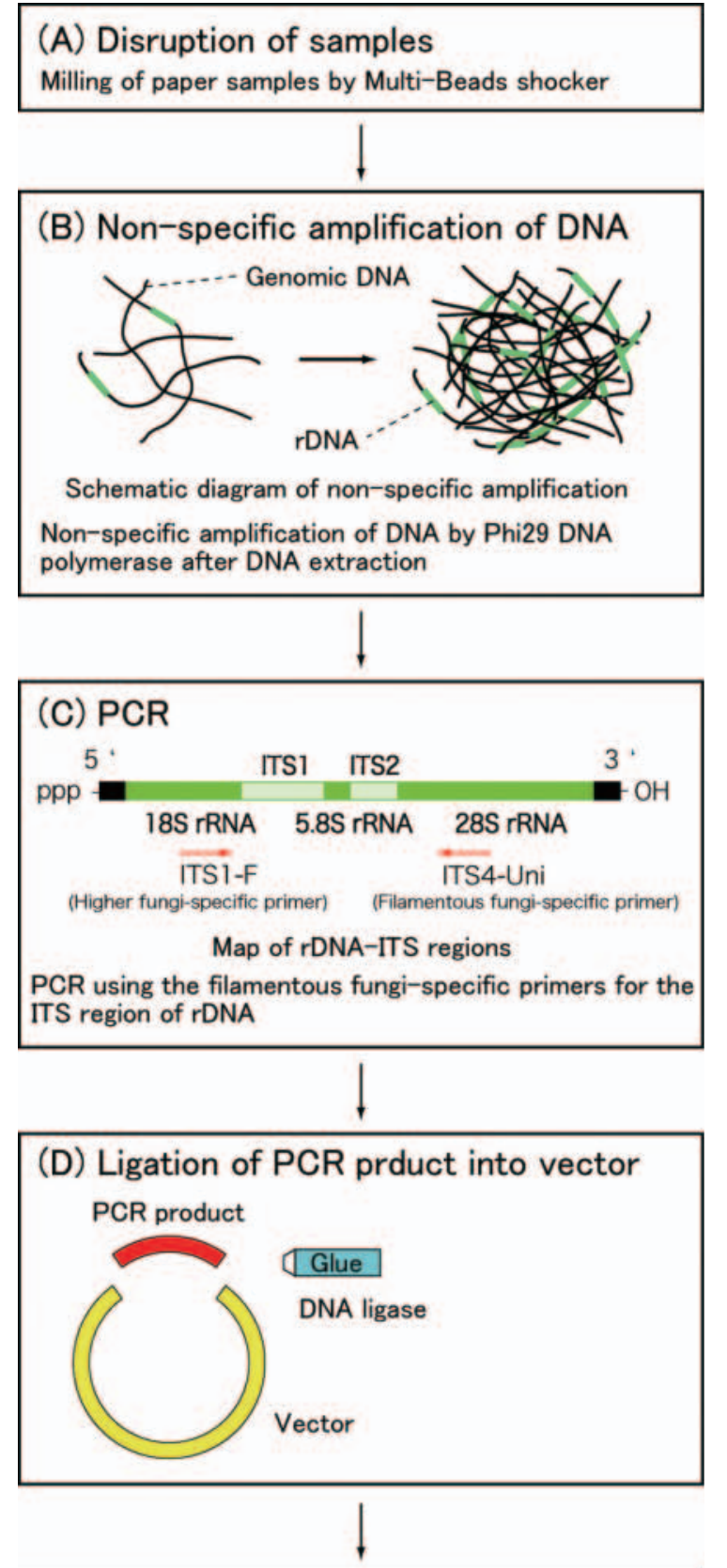

(E) Transformation into Escherichia coli

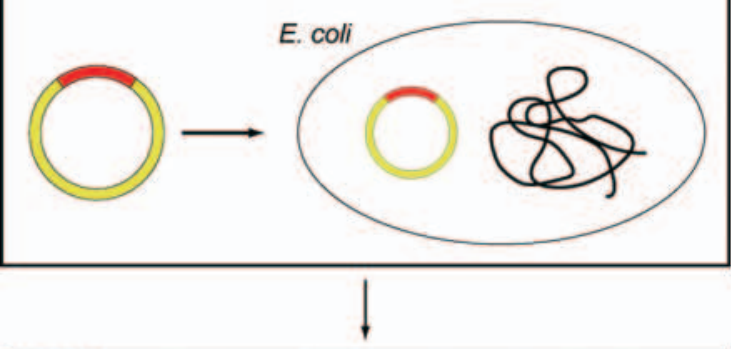

(F) Sequence analysis

Identification of the species by BLAST analysis using the DNA sequence

Fig.2 Experimental scheme of identification of filamentous fungi in paper.
ロジェン(株) にライゲーション（DNA リガーゼを使って DNA 断片同士をつなげる反応）し，さらに大腸菌（Escherichia coli,JM 109 Competent cells, タカラバイオ(株)の 形質転換を行った。なお，ベクターとは遺伝子を組み込む 相手として用いられる DNA のことであり，DNAリガー ゼとは DNA の切れ目をつなぐ酵素のことである。このよ うにして得たコロニー 12 個を任意に選択し，TempliPhi DNA Amplification Kit（GEヘルスケアバイオサイエンス (株) を用いてプラスミド DNA の増幅を行った。増幅され たプラスミド DNA を鋳型にDTCSクイックスタートキ ット（ベックマン・コールター(株）を用いてシーケンス反 応を行い, DNA シーケンサー (CEQ 8800,ベックマン・ コールター(株) によって ITS 領域の塩基配列を決定した。 得られた塩基配列を用いて, 米国立医学図書館の生物工学 情報センター（National Center for Biotechnology Information,NCBI）の相同性検索アルゴリズム（Basic Local Alignment Search Tool using a nucleotide query, BLASTN; http : //blast.ncbi.nlm.nih.gov/Blast.cgi）による解析を行 った。その際, 検索パラメータは, 全てデフォルトで行っ た。BLAST 検索による解析結果の中で最も相同性の高か った菌を近縁の種として同定した。

\section{3. 結果と考察}

\section{1 試料採取地周辺の海水の塩濃度}

外洋の海水の塩濃度は $3.1 \%$ から $3.8 \%$ であるが，日本 製紙石巻工場および三菱製紙八戸工場付近で採取した海水 は，近くの河口から流れ出る淡水と混じって外洋の海水の 塩濃度よりも低く，力ビの繁殖がほとんど抑えられる塩濃 度 $3.5 \%^{5-7)}$ よりも低いことが明らかとなった（Table 2)。 そのため東日本大震災で市街地を襲った津波は, 外洋の塩 濃度よりやや低い沿岸部の海水が，川の水と市街地の生活 排水や工場排水と混ざったものであったと推察される。し たがって，市街地を襲った津波の塩濃度は場所によってば らつきがあり, 河口付近や河口の上流では塩濃度の低い海 水か河川水であったことが予想される。紙が津波に浸って も，その塩濃度が低い時には塩水の浸透圧によるカビ抑制 効果が十分働かないため，紙にカビが生えてしまう可能性 がある。

\section{2 石巻工場で採取した津波被災紙の菌同定結果}

石巻工場で採取した 6 種の津波被災紙の紙試料から切り 取った試験片を Fig. 2 のスキームに従って PCR まで行っ た後, PCR 産物を電気泳動させた時に得られた写真を Photo. 4 に示す。両端は分子量マーカー ( $\phi$ X 174 Hae III digest, 夕カラバイオ(株) であり, 左端 2 番目から右へ順に 塗工紙（a)，（b)，（c), 上質紙（a)，（b)，（c）1，(c）2, (c) 3 の検体である。この結果から塗工紙 (b)，および上 質紙（c）の 3 検体全てから糸状菌だと推定される 600-800 $\mathrm{bp}$ 付近のサイズでバンドが検出された。目的のサイズの 単一バンドが検出された検体から系状菌の同定を行った結 果を Table 3 に示す。Population は検出された個体数, Sequence length は解読できた塩基配列の長さ, Accession Number は BLAST 検索による解析結果の中で最も相同性 
Table 2 Salt concentration of sampled seawater

\begin{tabular}{lcc}
\hline Sampling spots of seawater & Refractometry & Electric conductivity \\
\hline Vicinity of Ishinomaki mill & $2.1 \%$ & $2.07 \%$ \\
Vicinity of Hachinohe mill & $2.8 \%$ & $2.73 \%$ \\
\hline
\end{tabular}

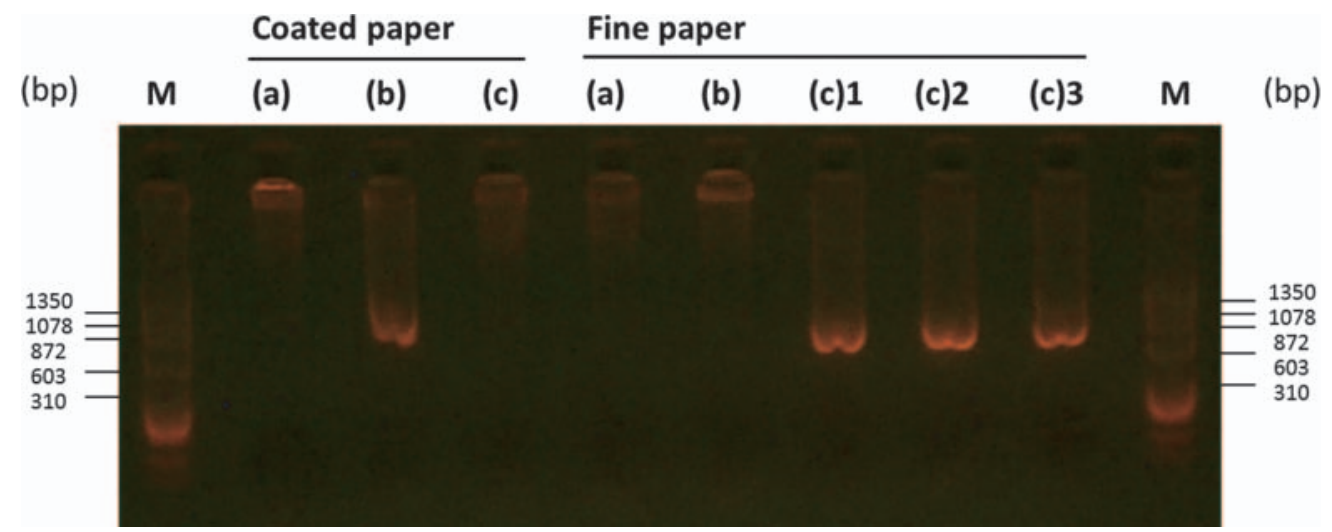

Photo. 4 Electrophoresis of PCR products prepared using filamentous fungi-specific primers. (a) Paper damaged by tsunami without mud, (b) Paper undamaged by tsunami, and (c) Paper damaged by tsunami with mud. M : Size marker

Table 3 Kind of filamentous fungi detected in paper samples

\begin{tabular}{|c|c|c|c|c|c|}
\hline Sample & Population & $\begin{array}{c}\text { Sequence } \\
\text { length }\end{array}$ & $\begin{array}{l}\text { Accession } \\
\text { Number }\end{array}$ & Species & $\begin{array}{l}\text { Sequence } \\
\text { homology }\end{array}$ \\
\hline Fine paper $(\mathrm{a})$ & 0 & - & - & - & - \\
\hline Coated paper $(\mathrm{a})$ & 0 & - & - & - & - \\
\hline Fine paper $(b)$ & 0 & - & - & - & - \\
\hline \multirow{7}{*}{ Coated paper (b) } & & & GQ 161752.1 & Penicillium dipodomyicola & 100 \\
\hline & 8 & 603 & EU 833212.1 & Penicillium chrysogenum & 100 \\
\hline & & & AF 455544.1 & Penicillium commune & 100 \\
\hline & 1 & 509 & JN 198455.1 & Acremonium sp. & 99 \\
\hline & 1 & 472 & GU 910192.1 & Uncultured Malasseziales & 97 \\
\hline & 1 & 238 & JF 793539.1 & Penicillium chrysogenum & 87 \\
\hline & 1 & 452 & GU 910192.1 & Uncultured Malasseziales & 88 \\
\hline Fine paper $(\mathrm{c}) 1$ & 2 & 507 & JF 440581.1 & Alternaria alternata & 99 \\
\hline \multirow[t]{4}{*}{ Fine paper $(\mathrm{c}) 2$} & 7 & 376 & EU 497953.1 & Acremonium strictum & 99 \\
\hline & 2 & 563 & EF 540755.1 & Geomyces pannorum & 99 \\
\hline & 2 & 472 & HQ 711617.1 & Alternaria tenuissima & 99 \\
\hline & 1 & 315 & HQ 212337.1 & Uncultured Mrakia & 99 \\
\hline \multirow[t]{3}{*}{ Fine paper $(\mathrm{c}) 3$} & 7 & 582 & GQ 161752.1 & Penicillium dipodomyicola & 99 \\
\hline & 3 & 554 & AY 873967.1 & Geomyces pannorum & 98 \\
\hline & 2 & 597 & AY 873967.1 & Geomyces pannorum & 88 \\
\hline Coated paper $(\mathrm{c})$ & 0 & - & - & - & - \\
\hline
\end{tabular}


の高かった菌の個体の番号, Sequence homologyは試験 片から得られた各菌の塩基配列と最も相同性の高かった菌 の個体の塩基配列との合致率を表す。

津波に浸水した塗工紙（a）および上質紙（a）の試料で は，菌は検出されなかった。津波による浸水を免れた塗工 紙（b）および上質紙（b）の試料では，塗工紙（b）のみ Penicillium 属菌を中心とした糸状菌が検出された。塗工紙 （b）では，8個体は同じ塩基配列であり，BLAST 検索で 3 種の菌 (Penicillium dipodomyicola, Penicillium chrysogenum, Penicillium commune) と $100 \%$ の相同性であった。塗工紙 (b) では 12 個体中 8 個体が Penicillium 属菌であったこと から, Penicillium 属菌がこの紙試料の優占種（生物群集の 中で個体数または現存量が多い種）であることが判明した。 Penicillium 属菌（アオカビ）は湿気のある場所で紙によく 生え, 種の違いによって青緑色, 緑色, 黄色, 黄褐色, 褐 色など様々な色に紙を着色し, 色素は沈着する。一度沈着 した色素を取り除くことは困難であるため，これらの菌は 紙製品や紙文化財にとって有害な菌であると言える ${ }^{12)}$ 。塗 工紙（b）ではPenicillium 属菌を中心とした糸状菌が検出 されたのに対して，塗工紙（a）および上質紙（a）ではい ずれも糸状菌が検出されなかったことから, 紙試料の種類 に関係なく，津波に一度浸水することで菌の繁殖が抑えら れた可能性が示唆された。

上質紙（c）では，3つの試験片それぞれにおいて Alternaria 属菌, Penicillium 属菌, Acremonium 属菌が優占種と して検出された。泥中には非常に多くのバクテリア・菌が 存在し, かつ豊富な栄養分が存在するため, 泥の付着した 津波被災紙は湿度が高くなると菌が非常に成長しやすい状 態であったことが考えられる。土壤 $1 \mathrm{~g}$ には, $10^{8} \sim 10^{9}$ 個 の微生物が存在し ${ }^{13)}$, 海底から数百メートル下の堆積物に も $1 \mathrm{~cm}^{3}$ あたり $10^{6} \sim 10^{8}$ 細胞のバクテリアがいることが知
Uncoated paper

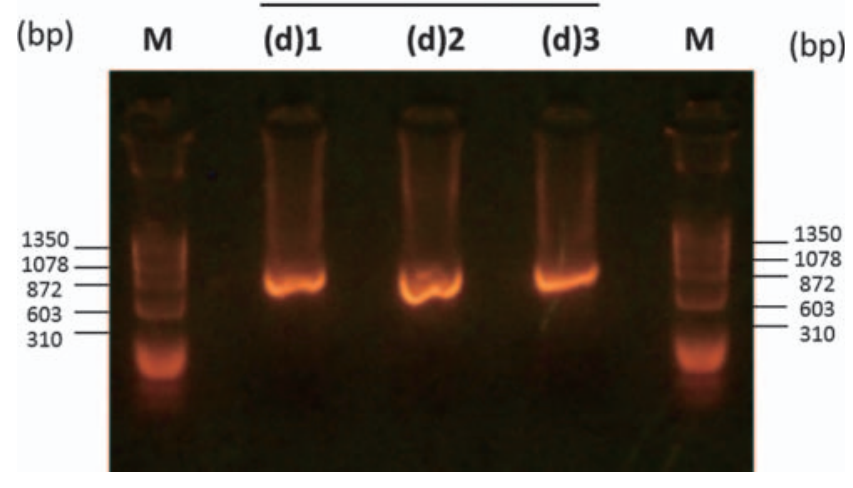

Photo. 5 Electrophoresis of PCR products prepared using filamentous fungi-specific primers. (d) $\mathrm{Pa}$ per damaged by tsunami and left outside for 3 months. $\mathrm{M}$ : Size marker

られている14)。

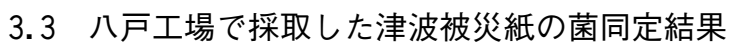

3.2 と同様に，八戸工場で採取した津波被災紙の紙試料 から切り取った試験片を Fig. 2 のスキームに従って PCR まで行った後, PCR 産物を電気泳動させた時に得られた 写真を Photo. 5 に示す。両端は分子量マーカーであり, 左 端 2 番目から右へ順に非塗工紙（d）1，(d）2，(d） 3 の検 体である。この結果から非塗工紙の 3 検体全てから糸状菌 だと推定される 600-800 bp 付近のサイズでバンドが検出 された。目的のサイズの単一バンドが検出された検体から 糸状菌の同定を行った結果を Table 4 に示す。

非塗工紙（d）の試料では，3つの試験片において Alternaria 属菌を中心とした糸状菌が検出された。非塗工紙 $(\mathrm{d})$ 1, (d) 3 では Penicillium 属菌が検出された。石巻工場で採

Table 4 Kind of filamentous fungi detected in paper samples

\begin{tabular}{|c|c|c|c|c|c|}
\hline Sample & Population & $\begin{array}{c}\text { Sequence } \\
\text { length }\end{array}$ & $\begin{array}{l}\text { Accession } \\
\text { Number }\end{array}$ & Species & $\begin{array}{l}\text { Sequence } \\
\text { homology }\end{array}$ \\
\hline \multirow[t]{7}{*}{ Uncoated paper $(\mathrm{d}) 1$} & 4 & 408 & AB 667801.1 & Alternaria alternata & 100 \\
\hline & 3 & 477 & JF 491202.1 & Alternaria solani & 100 \\
\hline & 1 & 519 & JN 572056.1 & Epicoccum sp. & 98 \\
\hline & 1 & 527 & AF 444629.1 & Leucosporidiella creatinivora & 99 \\
\hline & 1 & 429 & JN 038503.1 & Alternaria $\mathrm{sp}$. & 96 \\
\hline & 1 & 204 & JF 491202.1 & Alternaria solani & 98 \\
\hline & 1 & 446 & JN 572058.1 & Penicillium sp. & 98 \\
\hline Uncoated paper $(\mathrm{d}) 2$ & 12 & 566 & $\mathrm{AB} 667801.1$ & Alternaria alternata & 100 \\
\hline \multirow[t]{4}{*}{ Uncoated paper $(\mathrm{d}) 3$} & 5 & 610 & GU 566303.1 & Alternaria alternata & 100 \\
\hline & 4 & 622 & AF 444417.1 & Guehomyces pullulans & 99 \\
\hline & 2 & 533 & JF 704118.1 & Penicillium $\mathrm{sp}$. & 99 \\
\hline & 1 & 265 & FJ 210489.1 & Alternaria $\mathrm{sp.}$ & 96 \\
\hline
\end{tabular}


取した津波被災紙においても, Alternaria 属菌とPenicillium 属菌は検出されており, 少なくともこの 2 つの菌は, 紙に 繁殖しやすく着色をもたらす原因菌であることが判明した。 Alternaria 属菌（ススカビ）は植物（野菜）の病原菌とし て知られ，胞子が大きくて尖っているためアレルギー性鼻 炎や喘息などを引き起こすアレルゲンとしても知られてい る。非塗工紙（d）の試料は,八戸工場の敷地内で約 3 か 月間屋外放置されていた間に, 雨水や結露などの影響で紙 上の塩が流出し塩濃度の著しい低下が起こって, 浸透圧に よるカビ抑制効果が紙全体に十分発揮されなかったため力 ビが生えたと考えられる。

なお, 紙の繊維組成や塗工層の成分はカビの繁殖に影響 を及ぼしている可能性があり, その点に関しては今後の検 討課題である。

\section{4 塩水法の実用化に向けた具体的な処置法の考察}

3.1 の試料採取地周辺の海水の塩濃度測定結果から, 沿 岸部の海水の塩濃度は, 近くの河口から流れ出る淡水と混 じってカビの繁殖がほとんど抑えられる塩濃度 $3.5 \%$ より も低い可能性が高いことが明らかとなった。また海水には 多くのバクテリアが存在し, 生活排水, 工場廃水, 油など が混じっている可能性がある。そのため採取した海水を保 存塩水として使用する場合は, そのまま使用するのではな く, 塩濃度を高くする処置や海水を浄化する処置が必要で あることが明らかになった。

3.2 の石巻工場の津波被災紙の菌同定結果から, 紙に泥 が付着したままだと, 泥中の多種の菌や豊富な栄養分の存 在によって紙にカビが生えやすくなることが明らかとなっ た。このことから洪水や津波によって水害被災した紙に泥 が付着している場合は, 紙に付着した泥を, 真水で洗い流 した後にすぐに完全に乾燥させるか, 塩水で洗い流した後 に紙を塩水に浸漬させて緊急保存するのが望ましいことが 判明した。

3.3 の八工場の津波被災紙の菌同定結果から，紙が一 度海水に浸水しても屋外放置された場合には, 雨水や結露 などの影響で紙上の塩が流出し塩濃度の著しい低下が起こ って, 浸透圧によるカビ抑制効果が紙全体に十分発揮され なくなり, 紙にカビが生えてしまう可能性があることが示 唆された。このことから水害被災した紙を塭水に浸漬して 緊急保存する際には, 塩濃度の低下に気を付ける必要があ ることが判明した。

塩濃度 $3.5 \%$ 以上の塩水に紙全体を浸漬しておく処置は, 塩水の浸透圧によるカビ抑制効果が紙全体に働き，好気性 菌には酸素の遮断によるさらなる抑制効果があり, その後 の水洗浄及び吸水紙での拭き取りによる脱塩が可能である ため, 緊急保存の 1 つの選択肢として有効な処置であると 考えられる。

\section{4. 結 論}

日本製紙石巻工場および三菱製紙八戸工場付近で採取し た海水は, 近くの河口から流れ出る淡水と混じって外洋の 海水の塩濃度よりも低く, カビの繁殖がほとんど抑えられ る塩濃度 $3.5 \%$ よりも低いことが明らかとなった。そのた
め東日本大震災で市街地を襲った津波の塩濃度は，場所に よってばらつきがあり, 河口付近や河口の上流では塩濃度 の低い海水か河川水であったことが予想された。

日本製紙石巻工場の倉庫内で津波に一度浸水し自然乾燥 した塗工紙および上質紙の試料では菌は検出されなかった が，倉庫内で津波による浸水を免れた塗工紙の試料では Penicillium 属菌を中心とした糸状菌が検出された。津波に 一度浸水したことで塩水の浸透圧によるカビ抑制効果が発 現し, 紙が需れてから乾燥するまでにカビの繁殖が抑えら れた可能性が示唆された。一方, 倉庫内で津波に浸水して 泥が付着したまま自然乾燥した上質紙の試料では多種の系 状菌が検出された。泥中には非常に多くのバクテリア・菌 が存在し, かつ豊富な栄養分が存在するため, 泥の付着し た津波被災紙は湿度が高くなると菌が非常に成長しやすい 状態であったことが考えられる。この結果から洪水や津波 で水害被災した紙に泥が付着している場合は，泥中に存在 する菌や栄養分を除くために塩水か真水で泥を洗い流す工 程が必要であることが判明した。

三菱製紙八戸工場の敷地内で津波に浸水し約 3 か月間屋 外放置された非塗工紙の試料では Alternaria 属菌を中心と した糸状菌が検出された。屋外放置された津波被災紙は, 雨水や結露などの影響で紙上の塩が流出し, 塩濃度の著し い低下が起こったためカビが生えたと考えられる。この結 果から塩水保存中には塩濃度の低下に気を付ける必要があ ることが判明した。

\section{謝辞}

津波被災した紙試料および工場周辺の海水を採取して頂 きました日本製紙株式会社石巻工場の佐藤友治氏, 辻洋二 氏，三菱製紙株式会社八戸工場の菊池結衣氏に深く感謝申 し上げます。本研究は, 公益信託吉田学記念文化財科学研 究助成基金平成 22 年度研究助成, ソルト・サイエンス財 団 2010 年度研究助成, 三井物産環境基金 2011 年度東日本 大震災復興助成の支援を受けました。この場をお借りして， 深く感謝申し上げます。

\section{References}

1）木川りか, 佐野千絵, 喜友名朝彦, 立里臨, 杉山純多 : 保存科学 49, 231 (2009)

2)木川りか, 佐野千絵, 間㴊創, 喜友名朝彦, 立里臨, 西島美由紀，杉山純多：保存科学 48，167（2009）

3）佐藤隆一, 和田英己, 滝沢真紀, 横田勝弘: 医学と薬 学 49, 713 (2003)

4）梶浦工, 青木孝夫, 福武勝彦：基礎と臨床 31, 23 (1997)

5）東嶋健太, 江前敏晴, 五十嵐圭日子, 堀千明, 磯貝明, 坂本勇; 第 78 回紙パルプ研究発表会要旨集. 紙パル プ技術協会，東京，2011，P 156

6) Kenta Higashijima, Chiaki Hori, Kiyohiko Igarashi, Toshiharu Enomae, Akira Isogai : Studies in Conservation "First aid for flood-damaged paper using saltwater-Effect of saltwater on mold growth inhibition-" Accepted 22 November, 2011. (in press)

7）江前敏晴, 東嶋健太 : Cellulose Commmunications 18 (3) , 124 (2011) 
8）東嶋健太, 江前敏晴: 第 62 回日本木材学会大会要旨 集. 日本木材学会, 札幌, P 60

9）坂本勇：土地家屋調査誌 639 (4), 5 (2010)

10）和田朋子, 加治佐平，田中計実，五十嵐圭日子，鮫島 正浩：木材保存 35（2），57（2009）

11）和田朋子, 五十嵐圭日子, 鮫島正浩：木材保存 36 (5) , 200 (2010)
12）木川りか, 佐野千絵, 石崎武志, 三浦定俊：保存科学 46209 (2007)

13）西尾道徳：土壤微生物の基礎知識，農山漁村文化協会 1989, 25

14) R. J. Parkes et al : Nature 371, 410 (1994)

(受理：2012.2.16)

JAPAN TAPPI JOURNAL accepts scientific papers written either in Japanese or in English. We, JAPAN TAPPI, translate them into the other of the two languages (Japanese into English and English into Japanese) and print them in addition to the originals under the permission of the authors. We believe that this service of translation will help our subscribers to find and understand the scientific value of the original paper more clearly, and will contribute to the development of science and technology in the paper industry.

- The copy right of the translated version belongs to JAPAN TAPPI.

- If there is any inconsistency between the two versions, the original is always true.

- JAPAN TAPPI is not responsible to any outcomes based on the translated version. 